УДК [94:347.998.8:343.326] (477.74) «1768/1774»

DOI: https://doi.org/10.33782/eminak2019.2(26).286

\title{
ХАДЖИБЕЙ И ПРИЛЕГАЮЩЕЕ ПОБЕРЕЖЬЕ ЧЕРНОГО МОРЯ В ГОДЫ ПЕРВОЙ РОССИЙСКО-ТУРЕЦКОЙ ВОЙНЫ
}

\author{
Игорь Сапожников \\ Отдел Крыма и Северо-Западного Причерноморья \\ Института археологии НАНУ (Одесса, Украина) \\ e-mail: igors@gcn.ua \\ ORCID: https://orcid.org/0000-0003-3889-6714
}

Історія містечка та порту Хаджибей (Гаджибей) на березі Чорного моря протягом так званої Першої російсько-турецької війни 1768-1774 р. більш-менш непогано висвітлена вже опублікованими джерелами. Найвідомішими подіями цього періоду є два невдалі штурми османського замку запорожиями разом з регулярними російськими військами 1769 і 1770 рр., а також два епізоди 1774 р.: спроба турків відбити замок і випадіння значної кількості самосадочної солі на сусідніх лиманах.

Найбільш дискусійним є час взяття під контроль російських військ Хаджибейського замку, який деякі вчені помилково відносять до 1774 р. Аналіз наявної інформації дозволив автору уточнити, що це сталося від середини травня до початку вересня 1771 р., але, найвірогідніше, під час заходу сюди човнів першої частини запорозької флотилії Якова Шидловського між 17 та 21 травня 1771 р. Особливо цікавим і перспективним для дослідження є період перемир'я між Російською імперією та Портою Оттоманською 3 травня 1772 і до кінця лютого 1773 років. Саме тоді кораблі Дунайської військової флотилії активізували гідрографічні зйомки прибережної зони Північно-Західного Причорномор'я від гирл Дунаю до Очакова, матеріали яких лягли в основу цілої низки морських $і$ топографічних карт.

Ключові слова: Хаджибей, Північно-Західне Причорномор'я, російсько-турещька війна 1768-1774 рр., походи запорозьких козаків, взяття Гаджибейського замку, Дунайська флотилія, морські карти

История местечка и порта Хаджибей, который в российских источниках того времени назывался Гаджибей, реже - Аджибей, в 1768-1774 гг. известна в общих чертах, в основном, по неудачным штурмам османского замка запорожцами и регулярными войсками Российской империи (в 1769 и 1770 гг.), а также по двум эпизодам 1774 г.: попыткой турок отбить замок и выпадением самосадочной соли на лиманах «около Хаджибея»1. Исходя из этого Т.Г. Гончарук заявил, что на вопрос: «Когда во время войны 1768-1774 гг. российские войска овладели Хаджибеем?... историческая литература не дает точного ответа» ${ }^{2}$, хотя незадолго до этого тот же автор, вслед за А.А.Скальковским, заявил однозначно: «Хаджибей було взято... лише на початку 1774 року»3. Поэтому, не вступая в бесполезную дискуссию о степени «точ-

\footnotetext{
1 Хаджибей - Одеса та українське козацтво: 1415-1797 роки. / Відп. ред. І.В. Сапожников. Одеса: ОКФА, 1999. С. 37-44; Історія Хаджибея (Одеси) 1415-1795 рр. в документах. / Упор. та ред. Т.Г. Гончарук. Одеса: Астропринт, 2000. С. 87-101, 108-110.

2 Гончарук Т.Г. Військові операції на території сучасної Одещини під час російсько-турецьких війн XVIII ст.: методичний посібник. Одеса: Астропринт, 2002. С. 27.

3 Гончарук Т., Гуцалюк С. Українське козацтво і Хаджибей (Одеса): середина XVI ст. - 1794 р. Одеса, 1988. C. 15.
} 
ности в истории», подчеркну, что уже сейчас мы можем максимально приблизиться к обоснованной датировке данного события.

Имеющиеся опубликованные письменные источники позволяют утверждать, что Хаджибей был захвачен ранее весны 1772 года. Об этом четко говорится в донесения командира второй частью казацкой флотилии, полковника Ивана Мандра: «я с командою, с 7 против 8 прошлого мая мимо крепость Очаковскую и Кинбурнскую прошел благополучно, а маршируя оным морем, первую имели пристань при Аджибеи, где, простоявши до полтора дня [здесь и далее курсив автора статьи], приняли путь даже до Аккермана. Мая же 20 числа с Аккермана даже до Дунайского гирла как проследовали...»4. Из цитаты видно, что в Хаджибейском заливе отряд запорожских лодок не только останавливался, но и причаливал к берегу, а значит в указанное время вся Хаджибейская гавань с пристанью и замком находилась под контролем российских войск.

В свете сказанного нелогичным выглядит еще одно утверждение Т.Г. Гончарука о том, что, «згідно з описом, в архіві Запорозького Коша є документи про те, як одна 3 частин козацької під час переходу до Дунаю в 1772 р. спалила Хаджибей та захопила поблизу Дальника 7000 ногайських коней»5. В действительности, в описи архивных дел Коша, составленной знатоком запорожской истории А.А. РябининымСкларевским, речь идет о действиях двух морских казацких команд под руководством Якова Шидловского (Седловского) и Ивана Мандра, которые проследовали хаджибейскими водами до Дунайских гирл в 1771 и 1772 годах соответственно, причем «інша [вернее перша из них - явная опечатка] пройшла між Кінбурном і Очаковим, досягла Дністровського лиману, спаливши турецьке село Хаджибей...» и т.д. ${ }^{6}$

Известно, что первая часть казацкой флотилии Я. Шидловского на 19 лодках «посетила» Хаджибей между 17 и 21 мая 1771 г.7 В ходе данного «визита» казаки снова сожгли это местечко и в принципе именно с этим походом можно связать утрату османами Хаджибейского замка. Однако А.А.Скальковский, не вдаваясь в детали, сообщил о ряде других боевых столкновений казаков главного отряда Запорожского войска и подразделений российской армии с турецкой армией, имевших место с июня по начало октября 1771 г. «большей частью близ Очакова и Хаджибея»8.

Из этого, почти глухого тупика помог выйти документ, который просто выпал из хаджибейской историографии из-за невнимательности упомянутого автора. В нем идет речь о событии, имевшем место 14 сентября 1771 г.: «По содержанию рапорта бендерского коменданта полковника Коррета, подходили 14 числа от Ачаковской стороны два большие и два малые судна с пушками к Гаджибейскому замку и силились с пушечным и ружейным огнем выйти па берег; но тамошний постодержатель капитан Андреев супротивной стрельбой их к тому не допустил. Почему сии суда, простояв двое суток в таком расстоянии, где наши пушки вредить им не могли, и,

\footnotetext{
${ }_{4}^{4}$ Скальковский А. Дунайцы // Временник Императорского Московского общества истории и древностей российских. 1854. Кн. 19. С. 24.

5 Історія Хаджибея (Одеси) 1415-1795 рр. в документах... С. 104.

${ }^{6}$ Архів Коша Нової Запорозької Січі: опис справ. 1713-1776 pp. / Упор. Л.З. Гісцова. Київ: Наукова думка, 1994. С. 132.

7 Журнал военных действий ее императорскаго величества первой армии под предводительством генерал-фельдмаршала, графа П.А. Румянцева 1771 года. Санкт-Петербург. без года. Запись от 22 мая.

8 Скальковский А. История Новой Сечи или последнего Коша Запорожского. Составлена из подлинных документов Запорожского Сечевого архива. Ч. III. Одесса: Тип. А. Шульце, 1886. С. 83.
} 
произведя бесплодную стрельбу на стоявшую у пристани нашу стражу возвратились опять к Очакову»9. Как видим, в сентябре 1771 г. в Хаджибейском замке «на посту» находился отряд российских войск под командой капитана Андреева, подчиненный полковнику Елецкого полка, коменданту Бендерской крепости И. Коррету. Весьма примечательно, что это событие почти аналогично попытке турок вернуть Хаджибей путем высадки морского десанта, которая была совершена 2 мая 1774 г. в 2 верстах (к востоку - ?) от замка в урочище Татарское селище $e^{10}$.

Опираясь на приведенные факты, дату взятия Хаджибейского замка можно еще больше сузить от середины мая до начала сентября 1771 2., но автор склоняется к заключению, что, скорее всего, замок пал в мае 1771 г. в результате активных действий морской запорожской команды Я. Шидловского. Тогда казакам удалось захватить (и перегнать румом в Кош) до 7000 коней поблизости ногайского аула, балки или лимана Даллык ${ }^{11}$, то есть не менее, чем в 12-16 км от порта Хаджибея (ныне село и балка Дальник, а также лиман Сухой). Пехотный десант запорожцев состоял из 28 человек от каждого куреня, а весь отряд начитывал до 1000 казаков с 19 куренными атаманами (по одному на каждой лодке) ${ }^{12}$. Не исключено, что это мог быть не штурм замка как таковой, а тотальное уничтожение местечка пожаром, в результате которого гражданское население, а за ним и сам вражеский гарнизон, оставили замок до своего возвращения сюда уже по окончанию войны в 1775 г.

Замечу, что данное событие не могло состояться с мая 1772 - до конца февраля 1773 годов, когда воюющие стороны находились в состоянии перемирия, а также на протяжении всего 1773 г., так как 15 апреля того года для «содержания оповещательных постов от Аккермана сей стороной до Бендер, а той стороной Днестра до устья оного и реки Тилигула и замка Гаджибея» был назначен полк донских казаков полковника Карпова, а для его подкрепления «на той стороне Днестра в удобном месте» должны были расположится еще два полка - малороссийский Лубенский и карабинерный Пермский 13 .

Предложенная датировка взятия Хаджибейского замка неожиданно нашла подтверждение в надписи на каменном лапчатом казацком кресте, который до сих пор стоит на могиле «младенца Иоанна», расположенной на Куяльницком кладбище в предместье Одессы близ с. Усатово. По одной из версий, вырезанная на этом памятнике дата может быть прочитана как 1711 или 177114. Теперь же вторая дата стала гораздо более вероятной, поскольку присутствие украинского казацкого населения на протяжении четырех лет (с мая 1771 и до весны 1775 г.) в этом районе из почти фантастической версии перешло в разряд обоснованной научной концепции с осязаемым свидетельством в виде каменного надгробного памятника.

Возвращаясь назад, замечу, что почти годовой период российско-турецкого перемирия освещен в хаджибейской историографии лишь одним документом о вынужденном заходе в Очаков из-за шторма в июле 1772 г. российского судна под ко-

\footnotetext{
9 Журнал военных действий... 1771 г. Запись от 22 сентября.

10 Петров А.Н. Война России с Турцией и польскими конфидератами с 1769 по 1774 гг. Т. V: год 1774. Санкт-Петербург: Тип. Э. Веймара, 1874. С. 30; См. также: Хаджибей - Одеса та українське козацтво... С. 15, 43.

${ }_{11}^{11}$ Архів Коша... С. 132.

12 Скальковский А. Дунайцы... С. 13-14.

13 П.А. Румянцев / Ред. Г.П. Мещеряков. Т. II: 1768-1775. Москва: Воениздат, 1953. С. 597.

14 Сапожников И.В. Каменные кресты предместий Одессы (конец XVIII-XIX вв.). Ильичевск: Элтон 2-Гратек, 1999. С. 61, Рис. 20, 1.
} 
мандой капитана-лейтенанта И.Л. Ломана, экипаж которого выполнял гидрографические работы (Прил. 3-4), а также разведку и составление планов очаковских укреплений ${ }^{15}$. Т.Г. Гончарук включил этот документ в свою «хаджибейскую сводку» на основании того, что легендой для прикрытия этой операции была доставка из Измаила в Аккерман и Гаджибей продовольствия 16 , хотя в этом рейсе, который длился с 14 июня по 30 июля 1772 г., захода в Хаджибей, по-видимому, не было17. Это предположение подтверждается наличием «Карты от устья реки Днестра по берегу Черного моря до замка Гаджибея... с показанием при Гаджибейском порте глубины фарватера», снятой в 1774 г. (Прил. 10).

Тем не менее, этот эпизод интересен с точки зрения истории «первой» Дунайской военной флотилии, которая была сформирована в октябре 1770 г. в Измаиле «для описания устья рек Днепра, Днестра и Дуная», другими словами: для выполнения гидро- и картографических работ во всей прибрежной зоне Северо-Западного Причерноморья ${ }^{18}$. Без всякого сомнения, данные исследования затронули и Одесский залив вместе с окрестностями Хаджибея, но эта сторона деятельности названной флотилии пока недостаточно освещена в литературе ${ }^{19}$. Детальный обзор их хода и результатов выходит за рамки статьи, но список карт и планов, снятых служащими этой флотилии на протяжении 1770-1774 годов (Прил.), является прекрасной иллюстрацией сказанному. Беглый анализ этого, надо полагать, неполного перечня показывает, что на 7 из, примерно, 15 известных морских и речных карт СевероЗападного Причерноморья того периода изображен Хаджибей и прилегающее к нему побережье, но, подавляющая их часть никогда не публиковалась.

Подводя итоги сказанному, отмечу, что анализ опубликованных письменных и перечня картографических источников позволил уточнить ход событий, имевших место в 1769-1774 годах в районе Хаджибея не только на земле (в основном связанных с тремя штурмами замка в 1769, 1770 и 1771 гг.), но и на море. Из последних речь идет о двух попытках высадки турецких морских десантов (1771 и 1774 гг.) и двух заходах сюда запорожских морских команд (1771 и 1772 гг.). Кроме того, можно допустить заход в Хаджибейскую гавань в самом конце октября - начале ноября 1774 г. двух лодок (Кущевского и Незамайского куреней), чудом спасшихся во время страшной бури у буджакских берегов (в ночь с 20 на 21 сентября) вместе с турецким томбасом, на которых находились 30 пушек и часть экипажей морских казацких команд ${ }^{20}$.

\footnotetext{
15 Архив военно-походной канцелярии графа П.А. Румянцева-Задунайского. / Сост. М.О. Судиенко. Ч. II: 1770-1774. Москва: Издание Императорского общества истории и древностей российских при Московском университете, 1865. С. 183.

16 Історія Хаджибея (Одеси) 1415-1795 рр. в документах... С. 104.

17 Материалы для истории русского флота. Ч. VI. Санкт-Петербург: Тип. Морского министерства, 1877. С. 746.

18 Материалы для истории русского флота. Ч. VI... С. 731.

19 Сапожников И.В., Кожокару В.М. Российские карты земель Юго-Западной Украины и Молдовы времен войны 1768-1774 гг. // Наукові записки Інституту української археографії та джерелознавства НАН України. 2001. Т. 6. С. 189-194; Шпитальов Г. Дунайська флотилія (1771-1775 pp.) // Чорноморська минувшина. 2017. Вип. 12. С. 40-78.

20 Скальковский А. Дунайцы... С. 28-29.
} 
Приложение

\section{Список карт и планов, снятых служащими Дунайской флотилии в 1770-1774 годах ${ }^{21}$}

1. Карта части Безарабии [так в оригинале] от реки Прута до города Килии с показанием компонентов, движения и атак российской императорской армии против турок под предводительством главнокомандующего первою армиею, господина генерал-фельдмаршала и разных орденов кавалера, графа Петра Александровича Румянцева, сентября 9-го дня 1770 году. 1770 г. Копировал штурман Артамон Михайлов. М: 3 версты в дм /61х82 см/ (РО РНБ, ф. 885, д. 232, л. 19).

2. План бывшего поиска над неприятелем, находящегося при Дунае в местечке Тульче с российской стороны Измаила под командою генерал-майора Вейсмана с 700 гренадеров по большей части на рыбачьих лодках и без пушек 24 мая 1771 году, а турок было 5000. 1771 г. Сочинил бывший при той атаке флота капитан-лейтенант Егор Маврин. М: 250 саж. в дм /47х36/ (РО РНБ, ф. 885, д. 232, л. 21-1).

3. План бывшего поиска над неприятелем, находящегося при Дунае в городе Исакче с российской стороны Измаила под предводительством его превосходительства генерал-майора и кавалера Отто Ивановича фон Вейсмана 16 апреля 1771 году, гренадер при той атаке было 1700 чел., а турок 10000 чел. 1771 г. Сочинил бывший при той атаке флота лейтенант Ломан. М: 250 саж. в дм /47х26 см / (РО РНБ, ф. 885, д. 232, л. 21-2) 22.

4. Карта реки Дуная. Первая часть от местечка Мочина [Мачина] до мыса Чатала со впадающими в оную рек и озер с промером оных глубины, сочиненная при команде флота капитана первого ранга Нагаткина в городе Яссах 1771 года... М: 1 верста в дм (РО РНБ, ф. 885, д. 243/2, л. 37).

5. Карта части берега Черного моря от реки Дуная до Очаковского лимана. 1771-1772 гг. М: 13,5 верст в дм (РГВИА, ф. 846, оп. 16, д. 23529).

6. Карта берега Черного моря от Очакова до устья Дуная с промером глубины. 1772 г. М: 6 верст в дм (РГВИА, ф. 846, оп. 16, д. 23609)23.

7. Карта береговой части Черного моря от устьев Дуная до Очаковского лимана. 1772 г. М: 4 версты в дм (РГВИА, ф. 846, оп. 16, д. 23530).

8. Карта прибрежной части Черного моря от Аккерманского лимана до Очаковского. 1772 г. (РГВИА, ф. 846, оп. 16, д. 23532).

9. Положение реки Дуная от впадения ее в Черное море до устья реки Олта и протчих впадающих в нее рек с частью положения берега Черного моря. Сочинена с аккуратных описей 1771 и 772-го годов флота капитан-лейтенантов Егора Маврина, Ивана Ломана и лейтенантов Моселя Рындина и Савы Зубова. 1771-1772 гг. Копировал штурман Мирон Ядровцов. М: 4 версты в дм /73х225/ (РО РНБ, ф. 600, д. 232, л. 18).

10. План реки Дуная от Черного моря до устья реки Артыш с показанием поберегу от Рени

\footnotetext{
21 Список составлен по изданию: Карти і плани в джерелознавчих студіях Лідії Пономаренко (з описом картографічних джерел Інституту рукопису НБУ імені B.I. Вернадського та додатком відомостей про карти і плани з історії України в російських архівних та рукописних зібраннях) / упор. А.В. Пивовар. Київ: Академперіодика, 2012. С. 422-423, 458, 519, 523, 538-539, 559 и др.

22 Карты 2 и 3 нарисованы на одном листе. Существует их гравированный вариант на двух листах: План экспедициям, которыя производил г. генерал-майор Вейсман по приказанию г. генерала-фельдмаршала графа Румянцова 24/4 марта при Тулче и 16/27 апреля при Исакче, по ту сторону реки Дуная. Dessine par le Lieut. Colon. Mr de Stricker [Санкт-Петербург, Географ. департамент АН]. 48x70 (54x74) см. Есть в РНБ и др. библиотеках.

23 Эта карта описана под названием «План северной части Черного моря от устья Днепровского лимана до Георгиевского гирла Дуная, составленный с описей, произведенных в 1771-1772 гг. флота капитан-лейтенентами: Третьяковым, Мавриным, Ломаном и фон Дезиным, с промером». См.: Петрунь В.Ф. Первые русские карты окрестностей нынешней Одессы и их физикогеографическое содежание. ТОГУ. 1955. Т. 145. С. 143.
} 
до устья реки Яломищы лежащим местам. 1773 г. М: 4 версты в дм (РГВИА, ф. 846, оп. 16, д. 2302).

11. Карта от устья реки Днестра по берегу Черного моря до замка Гаджибея и по польской гранище до вершины реки Телигула с показанием при Гаджсиейском порте глубины фарватера. 1774 г. (РГВИА, ф. 846, оп. 16, д. 20214).

12. План местности реки Дуная в районе озера Кагаргуй [Кугурлуй]. Ранее 1775 г. С текстом на франц. языке, /47x63/ см. (СПБАРАН, р. IX, оп. 1а, д. 309).

13. Карта нижнего течения реки Дуная от города Браилова до устья с промерами глубин и дополнительными картами некоторых участков реки в укрупненном масштабе. М: 2 версты в дм (РО РНБ , ф. 885, д. 243/2, л. 36).

14. Схематическая карта нижнего течения реки Дуная /118х98/ (РО РНБ, ф. 885, д. 243/2, л. 33).

15. Carte du fleuve Dunabe... Карта реки Дуная от города Штирсова [Хыршова] до впадения в Черное море. Копировал К. Батуринов. М: 3 версты в дм /79х158/ (РОБРАН, д. 179).

16. Часть Черного моря от устья Дуная до Очаковской крепости. М: 5 верст в дм (РГВИА, ф.846, оп. 16, д. 23596).

17. Карта части Черного моря от Очакова до Карахармана, а от Кинбурна до Антудорского мыса [мыса Ай-Тодор]. М: 15 верст в дм (РГВИА, ф. 846, оп. 16, д. 23598).24

АН - Академия наук

\section{Список сокращений}

НАНУ - Национальная академия наук Украины / Національна академія наук України

РО РНБ - Рукописное отделение Российской Национальной библиотеки (Санкт-Петербург, РФ)

РГВИА - Российский государственный военно-исторический архив (Москва, РФ)

РОБРАН - Рукописный отдел Библиотеки Российской АН (Санкт-Петербург, РФ)

СПБАРАН - Санкт-Петербургское отделение Архива Российской АН

ТОГУ - Труды Одесского государственного университета имени И.И. Мечникова

\section{REFERENCES}

Arkhiv voenno-pokhodnoi kantseliarii grafa P.A.Rumiantseva-Zadunaiskogo [Archive of the Military Camping Office of Count P.A. Rumiantsev-Zadunaiski] (1865). Compiler M.O. Sudienko. Ch. II: 17701774. Moskva: Izdanie Imperatorskogo obshchestva istorii i drevnostei rossiiskikh pri Moskovskom universitete [in Russian].

Honcharuk, T.G. (2002). Viiskovi operatsii na terytorii suchasnoi Odeshchyny pid chas rosiisko turetskykh viin XVIII st: metodychnyi posibnyk [Military Operations on the Territory of the Modern Odessa Region at the Age of the Turkish-Russian Wars of the $18^{\text {th }}$ century: methodical assistance.]. Odessa: Astroprint [in Ukrainian].

Honcharuk, T., Hutsaliuk, S. (1988). Ukrainske kozatstvo i Khadzhybei (Odesa): seredyna XVI st. - 1794 [Ukrainian Cossacks and Hadjibey (Odessa): the Middle of the Sixteenth century - 1794]. Odesa [in Ukrainian].

Istoriia Khadzhibeia (Odesy) 1415-1795 rr. v dokumentakh [History of Hadzhibey (Odessa) 1415-1795 in Documents] (2000). Compiler T.G. Goncharuk. Odesa: Astroprint [in Ukrainian].

Karty i plany v dzhereloznavchykh studiiakh Lidii Ponomarenko [Maps and Plans in Source Studies Lidia Ponomarenko (With a Description of the Cartographic Sources of the Institute of Manuscripts of the National Bank of Ukraine named after V.I. Vernadsky and the Annex of the Information About Maps and Plans on the History of Ukraine in Russian Archival and Manuscript Collections)] (2012). Compiler A.V. Pyvovar. Kyiv: Akademperiodika [in Ukrainian].

P.A. Rumiantsev [P.A. Rumiantsev] (1953). Ed. G.P. Meshcheriakov. T. II: 1768-1775. Moskva: Voenizdat [in Russian].

Petrov, A.N. (1874). Voina Rossii s Turtsiei i polskimi konfideratami s 1769 po 1774 gg. [The War Between Russia and Turkey and Polish Confederates from 1769 to 1774]. T. V: god 1774. Sankt-Peterburg:

\footnotetext{
24 Карты 13-17 датированы в каталогах XVIII ст. и в принципе могут относится ко временам Второй российско-турецкой войны (1787-1791 гг.). Не исключено, что карта 4 является одной из составляющих частей карты 13.
} 
Tipografiia E. Veimara [in Russian].

Petrun, V.F. (1955). Pervye russkie karty okrestnostei nyneshnei Odessy i ikh fiziko-geograficheskoe sodezhanie [The First Russian Maps of the Area of Present-Day Odessa and Their PhysicoGeographical Content]. In Trudy Odesskogo gosuniversiteta im. I.I. Mechnikova, 145 (pp. 141-149) [in Russian].

Sapozhnykov, I.V. (1999). Kamennye kresty predmestii Odessy (konets XVIII-XIX vv.) [Stone Crosses of the Outskirts of Odessa (end of XVIII - XIX centuries)]. Ilichevsk: Elton 2-Gratek [in Russian].

Sapozhnykov, I.V., Kozhokaru, V.M. (2001). Rossiiskie karty zemel Yugo-Zapadnoi Ukrainy i Moldovy vremen voiny 1768-1774 gg. [Russian Maps of Lands of South-Western Ukraine and Moldova During the War of 1768-1774]. In Naukovi zapysky Instytutu ukrainskoi arkheografii ta dzhereloznavstva NAN Ukrainy, 6 (pp. 189-194) [in Russian].

Skalkovskii, A. (1854). Dunaitsy [Dunibians]. In Vremennik Imperatorskogo Moskovskogo obshchestva istorii i drevnostei rossiiskikh, 19 (pp. 9-30) [in Russian].

Skalkovskii, A. (1886). Istoriia Novoi Sechi ili poslednego Kosha Zaporozhskogo. Sostavlena iz podlinnykh dokumentov Zaporozhskogo Sechevogo arkhiva [The History of the New Sich or the Last of Zaharozhsky's Kosh. It is Made Up of Authentic Documents of the Zaporozhye Sich Archive]. Ch. III. Odessa: Tipografiia A. Shultse [in Russian].

Khadzhybei - Odesa ta ukrainske kozatstvo: 1415-1797 roky [Hadjibey - Odessa and the Ukrainian Cossacks: 1415-1797] (1999). Ed. I.V. Sapozhnykov. Odesa: OKFA [in Ukrainian].

Shpytalov, G. (2017). Dunaiska flotyliia (1771-1775 rr.) [Danube Flotilla (1771-1775)] In Chornomorska mynuvshyna, 12 (pp. 40-78) [in Ukrainian].

\section{Igor Sapozhnikov}

(Department of the Crimea and the North-Western Black Sea Region, Institute of Archaeology National Academy of Sciences of Ukraine, Odesa, Ukraine)

ORCID: https://orcid.org/0000-0003-3889-6714

\section{Khadjibey and Adjacent Coast of the Black Sea during the First Russo-Turkish War}

The history of the town and the port of Khadjibey (Hadjibey) on the Black Sea coast during the so-called First Russo-Turkish War of 1768-1774 is more or less described in already published sources. The most famous events of that period were two unsuccessful assaults of the Ottoman castle by the Zaporozhian Cossacks along with the regular Russian troops in 1769 and 1770, as well as two episodes in 1774: the Turkish attempt to recapture the castle and the appearing of a significant amount of lake salt in the adjacent estuaries.

The most disputable is the date of capturing of the Khadjibey castle by the Russian troops, which some scholars dated 1774 . The analysis of the available information allows the author to specify that this happened from the middle of May to the beginning of September 1771, but most likely during the coming of the first part of the Zaporozhian flotilla of Yakiv Shydlovsky between May 17 and 21, 1771. Particularly interesting and promising for the research is the period of truce between the Russian Empire and the Ottoman Porte from May 1772 to the end of February 1773. It was then that the ships of the Danube Military Flotilla intensified hydrographic surveys of the coastal zone of the North-West Black Sea region from the mouths of the Danube to Ochakiv, the materials of which formed the basis for a series of nautical charts and topographic maps.

Keywords: Khadjibey, North-West Black Sea region, Russo-Turkish War of 1768-1774, raids of the Zaporozhian Cossacks, the capture of the Khadjibey castle, Danube flotilla, nautical charts 